\title{
Penetration and Prevalence of Strategic Management in Higher Education Institutions in India
}

\author{
Dr. Sahil Sawhney ${ }^{1}$, Kulwant Kumar Sharma ${ }^{2}$, Prof. Ankur Gupta ${ }^{3}$ \\ ${ }^{1}$ Model Institute of Engineering and Technology, Jammu \\ ${ }^{2}$ Chitkara University, Punjab \\ ${ }^{3}$ Model Institute of Engineering and Technology, Jammu
}

\begin{abstract}
Strategic Management(SM) is an established global practice for deriving competitive advantage, driving organizational excellence, building business resilience and continuity besides ensuring long-term sustenance. SM has found widespread adoption in Higher Education Institutions in the western world with leading institutions implementing $\mathrm{SM}$ to create unique value propositions and strengthening their positions at the top of the global rankings. The Indian Higher Education system which is one of the largest in the world is at an inflection point. The focus has clearly shifted from increasing Gross Enrollment Ratio (GER) to improving quality and aspiring for excellence in all spheres despite the numerous challenges. The premise of this paper is to examine the extent of adoption of Strategic Management as a tool for achieving institutional excellence and sustenance within IHE through a survey of 368 leaders from higher education institutions across India. The survey uncovers interesting insights into awareness, prevalence and penetration levels across different categories of institutions.SM Maturity in the SM practicing institutions is assessed while leadership and institutional readiness with respect to SM adoption is
\end{abstract}

\section{Dr. Sahil Sawhney}

Model Institute of Engineering and Technology, Jammu evaluated. Finally, the institutional challenges in broad-basing adoption of strategic management and improving its effectiveness are discussed.

Keywords: Strategic Management, Indian Higher Education,

\section{Introduction}

Strategic management had its origins in the military with primary applications in war scenarios to out-maneuver the enemy (Nickols, 2011). It was subsequently adopted by businesses as a tool for driving competitive advantage, organizational excellence, long-term survival and sustenance. Chandler (1962) further defines strategy as "the determination of the basic long-term goals of an enterprise, and the adoption of courses of action and the allocation of resources necessary for carrying out these goals". According to Griffin (1990) strategy-making is concerned with "formulating and applying strategies for promoting a superior alignment between the organization and its environment and the achieving of strategic goals".

The Indian Higher Education (IHE) sector has witnessed unprecedented growth in terms of number of universities and private institutions resulting in a Gross Enrolment Ratio (GER) of $20 \%$ which is in a consistent upward trend (UGC, 2015). However, this exponential growth coupled with policy lacunae and lack of scientific manpower planning has led to issues 
of quality and effectiveness (Gupta, 2005).For the first time since independence the IHE is in the midst of a recession with declining enrollments especially in technical education and allied areas. Lack of professional management of individual institutions is perceived as a major contributor to the prevailing scenario with several institutions in the private sector confronted with disruption and existential concerns. In this rapidly changing landscape, these institutions are being forced to implement reforms and invest in quality to ensure survival. Thus, a study of the interventions being formulated and implemented along with their impact across IHE assumes significance. Since, SM is an established global practice to ensure survival and sustenance, this research paper examines the extent of adoption of SM in the IHE space especially in the tier-2 institutions which are located in the non-metro cities of India. We believe that such a study would lead to interesting insights into the perception of institutions in India towards SM and its adoption. The results can potentially form the basis for the development of a customized SM model aligned to the needs of tier-2 institutions in IHE to help enhance their competitiveness.

Very little research on the applicability of SM to IHE or case-studies related to institutional experiences on adoption of SM exists in India. This research paper is based on a survey of more than 350 leaders across various institutions in IHE to gauge institute/leadership perception, readiness, penetration, overall extent of prevalence and finally maturity level of implementation of SM in IHE. The survey brings out insights into why institutions are adopting SM and how institutions are approaching and implementing SM. Key challenges faced by institutions in institutionalizing SM are also identified.

\section{Literature Review}

The Greeks were the first to implement the concept of strategy in their military exercises. The word strategy is derived from Greek word "Strategos" which means a general in command of troops or the art of out-maneuvering enemies through effective utilization of available resources (Kozami, 2002). Strategic management thus had its origins in military with primary applications in war. It encompassed a way of thinking out of the box, taking initiatives and served as a tool for achieving victory in war. The concept of strategy since then has evolved and subsequently found adoption in business organizations as a tool for driving competitive advantage, achieving organizational excellence, long-term survival and sustenance. The major role of strategic management in the business organizations involved formulating plans to confront the threats and challenges posed by the external environment with effective utilization of skills, resources and manpower available within the system. Several researchers (Jauch \& Glueck, 1988; Kaplan \& Norton, 2001) have laid the foundation of strategic management for organizations and its importance through seminal work in the field. Mintzberg (1991) had established the roots of strategy to the times of Pericles (450 BC) as an organizational skill covering administration, management, leadership and communication culminating in power. Strategic management involves formulation and implementation of plans to achieve the major goals based on objective assessment of the internal and external environments in which the organization competes (Nag, Hambrick\& Chen, 2007). Porter (1980) defined strategy as the formula for organizations to set goals, policies and objectives to remain competitive in a dynamic environment.

The focus of strategic management is on the longterm survival and development of an organization (Stoner, 1978). Tabatoni and Barblan (2002), opine that the major objective of strategic management is to lead people involved in the progress of an institution and assist them to focus on the institution's brand image, raise question on its position in a new environment and ensure its continuous improvement and growth. According to Morden (2007) strategic management provides the framework for the organizations to make strategic decisions about customers and products, both financial and human resources, environment challenges, risks etc.

Thus, strategic management is an established management practice for creating a guiding framework for organizations helping them create a lasting vision, align themselves closely to their environment, actively explore new opportunities, build internal capacities and track their short and long-term execution to increase the likelihood of success. Since, then strategic management has evolved and been adapted to diverse domains and functions with equal measure of success.

2.1 Global Evolution of Strategic Management in Higher Education 
The Higher Education System worldwide has witnessed enormous changes such as global competition, geo-political concerns, reduced funding, increasing costs and declining customer satisfaction during the last decade. Scott-Clayton (2011) makes a mention of changing scenarios in higher education which have necessitated a change in management and leadership styles. The ever-increasing demand of external stakeholders (Taylor et al., 2000) for quality education, knowledge production, enhanced customer experience and wealth creation is putting enormous pressure on higher education institutions to continuously meet these expectations. In response, institutions worldwide have begun to adopt several measures including implementing SM to counter these challenges.

Strategic planning dominated the US business landscape and literature in the 1970s. The earliest mention of Strategic Management (SM) for non-profit organizations including higher education system is traced back to 1970 's, during the time when US higher education system was seeking to deal with reduced financial support, demographic challenges, lower enrollments, and resource mobilization (. Keller (1983) studied this relatively new trend in his book "Academic Strategy: The Management Revolution" and urged academic institutions to adopt a more strategic approach over incremental planning. According to Keller, strategic planning impacts the fate of the institution above all else.

Later Gibson (1994) stressed the need for strategic management for academic institutions which despite being collegial in nature can expect to benefit by adopting SM to face future challenges. Keller (1997) subsequently mentioned about the uniqueness of the academic setting and lay emphasis on strategic planning effectiveness in carving out a niche for the institutions and emerges as leaders. Hunt et al. (2010) state several reasons for implementing strategic planning in private higher education system, including:

- To improve performance toward meeting the mission statement;

- To improve performance toward increasing the academic standing;

- To increase accomplishments with the same or lower level of resources;
- To clarify the future direction of the institution;

- To meet the requirements of accreditation or of a government agency;

- To solve major problems (threats) or address significant opportunities.

The adoption of strategic management by institutions of US higher education rose dramatically during the mid-1980s and Cope (1987) through a survey found that 88 percent post-secondary institutions in the USA professed using strategic planning. Later, the strategic plan became a necessity for US universities and colleges as Western Association of Schools and Colleges made strategic planning a mandatory component for university accreditation. The survey carried out by Cotter and Paris (2007) in top 15 higher education institution in US in 2007 point out to the fact that all institutions surveyed had published strategic plans, while 90 percent of the institutions had long-term institution-wide strategic plans which were strongly aligned with the process improvement, reaccreditation, leadership development, fund raising, capital planning and reward structure.

A number of researches were made in evaluating the impact of strategic management in the Higher Education Institutions and the most prominent among them is one carried out in Peking University in China. (Xie, 2014) studied the case of Peking University of China with respect to the implementation of practice of Strategic Management. The university adopted the practice in the early 1990s with a vision to join the world ranks with in a time frame of two decades. The strategic planning led to significant changes in the organizational and cultural set which assisted the university in breaking the barriers of inadequate resources and obstinate faculty. The institution saw a huge surge in their world ranking within two decades and was ranked 48th as per the recent rankings declared by Times Higher Education World University Ranking. The author concluded the study with the comparison of the Strategic planning to the GPS system which with the help of a good driver would let the passenger travel and do its job in a hassle-free manner.

Strategic Management was subsequently adopted by other countries in the western world and now finds adoption in a majority of the leading institutions of the world. Table 1 below summarizes the advanced levels 
Table 1: Current State of Global SM adoption

\begin{tabular}{|c|c|c|}
\hline $\begin{array}{l}\text { Approximate Year } \\
\text { of Adoption of SM }\end{array}$ & Country & Current State and Impact of Strategic Management \\
\hline 1980 & $\overline{\text { USA }}$ & $\begin{array}{l}\text { Strategic Planning has become a well adopted } \\
\text { management practice in higher education. All the } \\
\text { institutions have detailed strategic plans available on } \\
\text { their website for transparency and public view. It's } \\
\text { mandatory for all institutions to have strategic plans for } \\
\text { University accreditation. }\end{array}$ \\
\hline $1984-1989$ & UK & $\begin{array}{l}\text { All the institutions were instructed by government to } \\
\text { come up with strategic plan }\end{array}$ \\
\hline 1986 & Europe & $\begin{array}{l}\text { The Centre for SM of European Universities was } \\
\text { created in } 1986 \text { with a vision to promote SM practice in } \\
\text { academic setup. In its recent Europe } 2020 \text { strategy there } \\
\text { was a push to increase the performance of institutions by } \\
\text { modernizing their governance and train their leaders to } \\
\text { work effectively in a competitive market environment. } \\
\text { A project "MODERN" launched under the le adership of } \\
\text { EUSM, is a consortium of } 10 \text { core and } 31 \text { associate } \\
\text { partners to prepare strategic plans for higher education } \\
\text { to work under external threats (Benneworth, 2011) }\end{array}$ \\
\hline 1990 & China & $\begin{array}{l}\text { Chinese government laid strong emphasis on enhancing } \\
\text { the international competitiveness of its higher education } \\
\text { institutions in the early 1990's in the form of Project } \\
211 \text { and Project } 985 \text {. Thereafter, universities laid down } \\
\text { strategic plans for the next two decades. This has } \\
\text { resulted in China moving up the international rankings } \\
\text { ladder and making their presence felt among top } 400 \\
\text { universities across the world. (Council, 2013) }\end{array}$ \\
\hline 1990 & $\begin{array}{l}\text { South } \\
\text { Korea }\end{array}$ & $\begin{array}{l}\text { Five Year Strategic Plans have been made mandatory } \\
\text { for all higher education institutions. }\end{array}$ \\
\hline
\end{tabular}

of SM adoption and maturity in select countries:

Several researchers have also questioned the applicability of strategic management to higher education. Among those prominent are Mintzberg (1994) and Schmidtlein and Birnbaum (2000) who have critically evaluated the impact of SM in higher education and presented a divergent view from the proponents of SM. They debunked the proposition of SM as a panacea for higher education. Birnbaum described strategic planning as a management fad in higher education asserting that the idea of strategic planning conflicts with the organizational culture of universities, where authority is broadly dispersed among academic communities. Birnbaum (2000) studied the impact of SM on universities and concluded that many universities spent extensive resources on strategic management without much impact.

However, the results of SM implementation over last three decades firmly strengthens its applicability to higher education institutions for achieving quality, excellence, superior performance, organizational effectiveness and long-term sustainability (Keller, 1983; Bryson, 1988; Bryson \& Alston, 1996; Hahn \& Powers, 1999; Austin, 2002; Pet-Armacost\& Wilson, 2004; Stukalina, 2014).

Thus, strategic management has been successfully adopted and implemented at higher education institutions with considerable level of success. The US and European countries, the early adopters of SM have been immensely benefitted in creating globally recognized institutions and sustaining their leadership positions over the years (Hinton, 2012). The global institutional ranking also reflects this fact. For instance, in the Times Ranking 2016, out of 400 global institutions more than 50\% were US and European institutions.

\subsection{Strategic Management in IHE}

The adoption of formal strategic management by institutions of Higher Education in India seems to be in a nascent state. Very little literature or published research exists in this domain. A review of the top 20 ranked technical institutions in India as per the National Institutional Ranking Framework (NIRF 2017) was carried out to gauge the prevalence of SM practice. IIT Madras (ranked 1stin NIRF) was the only institution which published its strategic plan on its website and has created a special full-time position to drive SM across the institution. IIT Bombay and IIT Kanpur ranked 2nd and 4th respectively have initiated the adoption of SM in 2017 only and their plans are currently in public domain for stakeholder feedback. IIT Delhi has created a specialized position of Director, Strategic Planning for adoption of SM but their plan is still not available in the public domain. However, the extent of institutionalization of formal SM in these institutions is still not clear. The adoption of SM is therefore still in its infancy in the top 20 technical institutions in India. Further, none of the top 20 private technical institutions featuring in NIRF 2017 had published their strategic plans on their respective websites.

A similar empirical study was carried among the top 20 institutions as per global TIMES Ranking 2017 to gauge the prevalence of SM practice among the top higher education institutions of world. All the institutions had well defined long term and short term plans, besides strategic plans available for specific areas such as faculty development, student experience, IT etc. available to the public on their institution website. The adoption of SM in these institutions is currently at very mature level.

SM has also not figured in the higher education policy and has also not caught the attention of the regulatory or statutory bodies governing higher education in India. The National Assessment and 
Accreditation Council (NAAC) and the National Board of Accreditation (NBA) have defined acomprehensive set of parameters for defining quality output and outcomes for institutions of higher education in India. NAAC framework is very comprehensive in laying down various parameters fewer than seven different criteria. However, NAAC or NBA does not specifically recognize strategic management adoption as an institutional best-practice under the criteria of governance and leadership, unlike in the USA where strategic management is a mandatory aspect of institutional accreditation.

Raghunandhan and Sequeria (2013) evaluated SM practice in Centrally-funded Technical Institutions (CFTI) of India and brought out the fact that most of the institutions were either not involved or lagging behind in the adoption of this important management practice which has immensely benefited institutions all over the world. The data also revealed the fact that around 95percent of the institutions were employing the conventional management practice of running institutions based on operational planning and management. There were absolutely no initiatives to redefine the management system as major decisionmaking positions were occupied by faculty members who didn't have the exposure, experience or the necessary leadership attributes for strategically managing the institutions. The institutions surveyed were seen lacking in accountability, transparency, and planning. The study recommended that CFTIs implement strategic planning for increasing their performance and accountability without further delay to stay relevant in a highly competitive global market. The study though excluded the private sector which accounts for 75 percent of the total institutions in IHE.

Raghunandhan (2009) emphasized on the importance of implementation of Strategic Planning and Management at the institution level for achieving excellence and upgrading their performance level. A theoretical model of Strategic Management based on the study of strategic models adopted by global universities was conceptualized and recommended for implementation.Prof. Yash Pal Committee constituted by the University Grants Commission (UGC) to suggest measures for renovation and rejuvenation of Indian Higher Education (Oct, 2008) expressed concerns over the governance model in IHE describing it as an undermanaged sectorin India. The Committee strongly recommended that structural changes be affected on priority to meet the expectations of stakeholders.Sawhney et al. (2016) have put forward a strong case for adoption and implementation of strategic management in IHE at the level of individual institutions besides having a nation-wide strategic plan for the higher education sector. Finally, no case-studies examining the impact of SM adoption in institutions in India over a significant time-period exist currently.

\section{Research Design}

\subsection{Objectives}

The objectives of this study are:

1. To assess the prevalence and penetration level of Strategic Management in institutions of Higher Education in India

2. To assess the maturity level of SM practice in these institutions.

3. To identify the challenges faced by these institutions in the implementation of Strategic Management

4. To understand the leadership perception and attitude towards SM adoption in their institutions

\subsection{Constructs}

The following constructs were established for the study:

Construct 1: Assess the penetration and prevalence of SM in the institutions

a. Degree and level of SM adoption among the surveyed institutions

b. Understand the process of SM implementation in the institutions

Construct 2: Assess the attitude of institutional leaders in IHE towards strategic management.

a. Evaluate general awareness about SM

b. Perception on importance of SM as leadership tool.

c. Perception of potential of SM in overcoming institutional challenges 
d. Inclination to adopt formal SM in respective institutions

Construct 3: Asses the maturity level of SM implementation in IHE

a. Categorize the maturity of SM implementation through The Strategic Management Maturity ModelTM

b. Identify Formal SM frameworks/tools implemented in IHE

For the present study, a questionnaire was used to measure the three defined constructs. The responses were measured on a 5-point Likert Scale:

5=Strongly $\quad$ Agree, $\quad 4=$ Agree, $3=$ Neutral, $2=$ Disagree, $1=$ Strongly Disagree

Demographic details of the respondents and institutions were also collected.

\subsection{Sampling Frame and Data Collection}

The survey questionnaire was mailed through Survey Monkey platform and webmail to more than 1000 people at leadership positions such as Chairpersons, Directors, Principals, Heads of Departments, and Deans etc. across several institutions. A total of 368 respondents filled in the survey.

The self-administered questionnaire comprising 42 questions was designed to meet the requirement of the research. Insights from existing literature and inputs from subject matter experts were used to design the questionnaire. Some of the questions were selfstructured to validate the research further and to cover the diversity of research problem. The questionnaire is divided into 6 different sections capturing the details spread across entire strategic management life-cycle i.e. from conceptualizing, adoption, and planning to implementation phase. The survey first captures the respondent and institution's demographic profile which is followed by questions on SM's-prevalence, process, maturity and challenges faced by leaders in its adoption. The reliability of the questionnaire was assessed using Cronbach's Alpha and found to be 'very good' $(>0.8)$.

The data was analyzed using SPSS 19. The t-test along with Pearson correlation analysis was performed to determine the interplay of leadership traits and background and institutional profile with the adoption of SM. Institution and respondent details captured during the survey are tabulated in Table 2 below:

Table 2 : Institution and Leadership Profiles

\begin{tabular}{|c|c|c|c|c|c|}
\hline \multicolumn{3}{|c|}{ Institutional Profile } & \multicolumn{3}{|c|}{ Leadership Profile } \\
\hline Variable & Classification & Description & Variable & Classification & Description \\
\hline \multirow{4}{*}{$\begin{array}{l}\text { Institution } \\
\text { Category }\end{array}$} & Private-Affiliated & $298(82.7 \%)$ & \multirow{4}{*}{ Gender } & \multirow[t]{2}{*}{ Male } & \multirow[t]{2}{*}{$297(80.70 \%)$} \\
\hline & Government & $31(8.61 \%)$ & & & \\
\hline & Autonomous & $18(5 \%)$ & & Female & $71(19.29 \%)$ \\
\hline & Others & $21(3.61 \%)$ & & & \\
\hline \multirow{4}{*}{$\begin{array}{l}\text { Institution } \\
\text { Type }\end{array}$} & Engineering & $140(38.04 \%)$ & \multirow{4}{*}{$\begin{array}{l}\text { Leadership } \\
\text { Position }\end{array}$} & Chairperson & $11(2.98 \%)$ \\
\hline & $\begin{array}{l}\text { Management } \\
\end{array}$ & 111(30.16\%) & & Director & $178(48.36 \%)$ \\
\hline & Multi-Disciplinary & $98(26.63 \%)$ & & Principal & $138(37.50 \%)$ \\
\hline & \begin{tabular}{|l} 
Others \\
\end{tabular} & $19(5.16 \%)$ & & Other & $41(11.14 \%)$ \\
\hline \multirow{4}{*}{$\begin{array}{l}\text { Accreditation/ } \\
\text { Certification }\end{array}$} & NAAC & $81(22.01 \%)$ & \multirow{4}{*}{ Age } & Greater than 60 & $64(17.78 \%)$ \\
\hline & NBA & $36(9.78 \%)$ & & Greater than 50 & $169(36.67 \%)$ \\
\hline & Others & $76(20.65 \%)$ & & Greater than 40 & $127(35.27 \%)$ \\
\hline & None & $175(47.55 \%)$ & & Less than 40 & $8(10.2 \%)$ \\
\hline \multirow[t]{4}{*}{ Region } & North & $115(31.94 \%)$ & \multirow{4}{*}{$\begin{array}{l}\text { Education } \\
\text { Qualification }\end{array}$} & Post-Doctorate & $18(4.89 \%)$ \\
\hline & South & $183(49.72 \%)$ & & Doctorate & $323(87.77 \%)$ \\
\hline & East & $25(6.79 \%)$ & & Post-Graduation & $12(3.26 \%)$ \\
\hline & West & $45(12.22 \%)$ & & Others & $15(4.07 \%)$ \\
\hline \multirow{4}{*}{$\begin{array}{l}\text { Student } \\
\text { Enrollment }\end{array}$} & $<1000$ & $83(22.55 \%)$ & \multirow{4}{*}{$\mid \begin{array}{l}\text { Industry } \\
\text { Experience in } \\
\text { years }\end{array}$} & Less than 5 & $268(72.82 \%)$ \\
\hline & 1000-3000 & $138(37.50 \%)$ & & $5-10$ & $87(23.64 \%)$ \\
\hline & $3000-5000$ & $126(34.23 \%)$ & & $10-20$ & 13(3.53\%) \\
\hline & $>5000$ & $21(5.70 \%)$ & & Greater than 20 & 0 \\
\hline \multirow[t]{4}{*}{ Location } & Urban & $161(43.75 \%)$ & \multirow{4}{*}{\begin{tabular}{|l} 
Total \\
Experience \\
In years
\end{tabular}} & Less than 15 & $7(1.90 \%)$ \\
\hline & Semi-Urban & $121(32.88 \%)$ & & $15-25$ & $128(34.78 \%)$ \\
\hline & Rural & $21(5.70 \%)$ & & $25-35$ & $201(54.61 \%)$ \\
\hline & Metro & $65(17.66 \%)$ & & Greater than 35 & $32(8.69 \%)$ \\
\hline
\end{tabular}

\subsection{Data Analysis}

The mean and associated t-values for each of the constructs defined for the study were computed. The one-tailed t-test was also applied to test the significance of the constructs. The null and alternate hypothesis for testing the constructs is defined as:

H0: Mean $<=3$ (median of the 5-point Likert scale used in the questionnaire)

\section{H1: Mean $>3$ (Median of the 5-point Likert scale)}

Table 3: Hypothesis Testing (Source: Author's Analysis)

\begin{tabular}{|l|l|l|l|}
\hline \multicolumn{1}{|c|}{ Construct } & Mean & t-value & Significance \\
\hline $\begin{array}{l}\text { Construct 1:Awareness, Penetration and } \\
\text { Prevalence of SM in the surveyed } \\
\text { institutions }\end{array}$ & 2.02 & -2.345 & $\begin{array}{l}\text { Not } \\
\text { Significant }\end{array}$ \\
\hline $\begin{array}{l}\text { Construct 2: Maturity level of SM } \\
\text { implementation in IHE }\end{array}$ & 1.37 & -4.789 & $\begin{array}{l}\text { Not } \\
\text { Significant }\end{array}$ \\
\hline $\begin{array}{l}\text { Construct 3: Attitude of institutional } \\
\text { leaders in IHE towards strategic } \\
\text { management. }\end{array}$ & 3.24 & 10.98 & Significant \\
\hline
\end{tabular}

The construct is considered to be significant if the tvalue associated with the test is greater than 1.96.

The data analysis reveals that the existing penetration and prevalence of SM in the higher 
education institutions along with the maturity level of SM adoption are not significant. However, the attitude of institutional leaders in IHE towards the strategic management was significantly positive. Thus, out of 3 constructs 2 were found to be not significant and one was significant.

\subsubsection{Correlation Analysis}

A bivariate correlation analysis was also undertaken to understand the relationship between prevalence and maturity of SM in the higher education institutions with quantifiable parameters from institution profile and leadership attributes for the $53 \mathrm{SM}$ practicing institutions. The results are summarized in the tables 4 and 5 below:

Table 4: Correlation Analysis (Institution Profile)

\begin{tabular}{|l|l|l|}
\hline \multirow{2}{*}{ SM Prevalence } & \multicolumn{2}{|c}{ Institution Variables } \\
\cline { 2 - 3 } & Age $=0.169$ & Student Enrolment \\
\cline { 2 - 3 } & Significant & Significant \\
\hline SM Maturity & $\mathrm{r}=0.065$ & $\mathrm{r}=0.187$ \\
\cline { 2 - 3 } & Significant & Significant \\
\hline
\end{tabular}

Table 5: Correlation Analysis (Leadership Attributes)

\begin{tabular}{|l|l|l|l|}
\hline \multirow{2}{*}{} & \multicolumn{3}{|c}{ Leadership Variables } \\
\cline { 2 - 4 } & Age & $\begin{array}{l}\text { Total } \\
\text { Experience }\end{array}$ & $\begin{array}{l}\text { Industry } \\
\text { Experience }\end{array}$ \\
\hline SM Prevalence & $\mathrm{r}=.143$ & $\mathrm{r}=0.289$ & $\mathrm{r}=.671$ \\
\cline { 2 - 4 } & Significant & Significant & Significant \\
\hline SM Maturity & $\mathrm{r}=0.169$ & $\mathrm{r}=.145$ & $\mathrm{r}=.734$ \\
\cline { 2 - 4 } & Significant & Significant & Significant \\
\hline
\end{tabular}

The prevalence and maturity of SM in the higher education institutions had a significant positive relationship with number of students enrolled and a weak positive correlation with the institution age. On the other hand, the industry experience of the leaders had a much more significant positive relationship with SM prevalence and maturity as compared to their age and the total experience.

\subsubsection{Discussion and Findings}

\subsubsection{Awareness and Penetration}

A majority of the leaders surveyed (286 out of 368) considered SM as an important leadership and transformation tool. The leaders (294 out of 368) further believed that the SM can prove as a viable countermeasure to the existing challenges faced by their institutions and help in drawing specific plans to address these challenges. 53 out of 368 institutions claimed to be practicing formal SM in their institutions with well-defined strategic plans and processes. The distribution of formal SM practicing institutions (53) on different institution parameters like location, institution type, accreditation and region is given below in Figures 1(a) and 1(b).

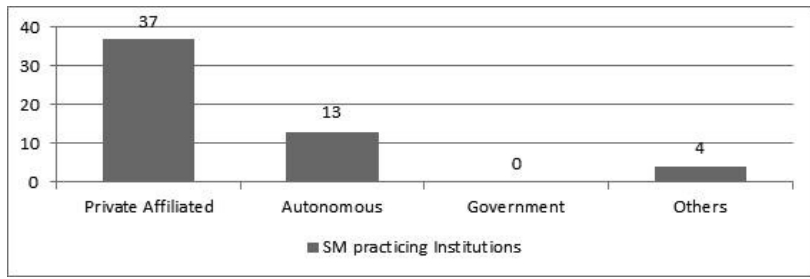

Fig 1(a).Distribution of SM practicing institutions by Institution Type

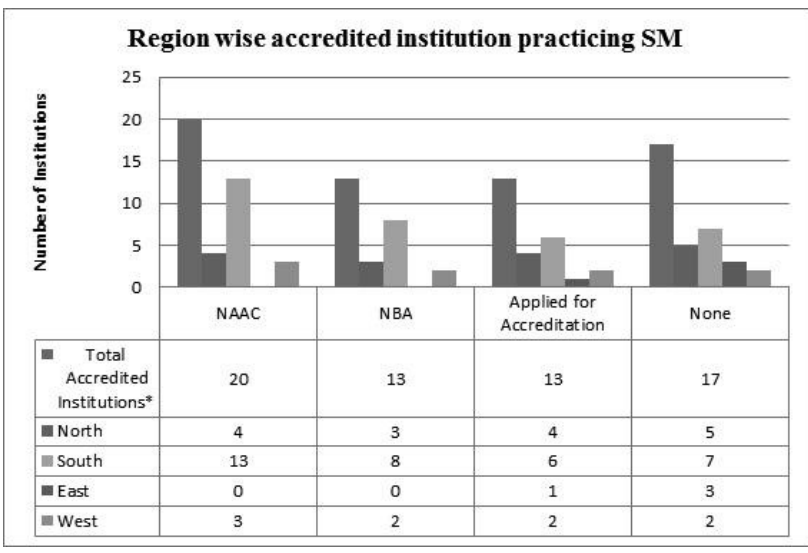

Fig 1(b). Accreditation status and region-wise distribution of SM practicing institutions

* 10 institutions were both NAAC and NBA accredited

SM is adopted majorly (37/53) by private affiliated institutions followed by autonomous (13/53) institutions with no adoption reported from Government institutions. This could be attributed to intense competition and decreasing trend of enrolments in private institutions. The penetration of SM practice among colleges in South India (34) is the highest followed by institutions in North India (16). 30/53 institutions were not accredited out of which 13/30 had applied for the accreditation. 20/53 and 13/53 institutions were NAAC and NBA accredited respectively. 


\subsubsection{Prevalence and Maturity of SM}

The questionnaire branched out further for institutions which responded in the affirmative to practicing formal SM. These questions assessed these 53 respondent institutions on the extent of prevalence and maturity of the SM processes adopted.

\section{A. Prevalence}

David, (2009) has described strategic management as a four-step process which involves initial assessment followed by formulation, implementation and tracking of strategic plans. The findings of SM prevalence for each step defined above are given below:

\section{- Initial Assessment:}

All 53 respondents claimed to have well-defined vision and mission statements but only 30/53 respondents felt that there existed a formal mechanism to review and deliberate upon institutional vision and mission statement. 27/53 institutions claimed to have developed an institution-wide strategic plan. Only 10 out of these 27 institutions had long-term strategic plans (3-5 years). Rest (17) was creating annual strategic plans. All respondents also felt that objectives, and plans further down did not stem from and hence were not aligned with vision and mission statement. Only 8/53 institutions had articulated their core values which form the basis of strategic management. Moreover majority (42/53) of the institutions didn't have department level strategic plans and none of the institutions had created transformational and enabling strategies and the associated plans for Risk Management, Student

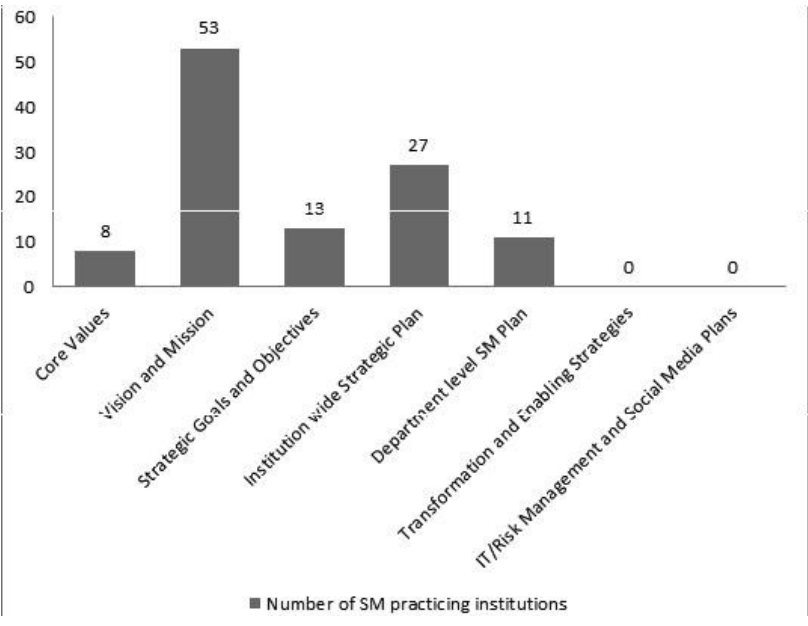

Fig 2. Typical SM Practices
Experience and IT strategic plan as shown in the Fig 2 below:

In majority (43/53) of the institutions, strategic plan was not aligned with financial budgeting and resource allocation which is considered to be integral part in strategic planning. $100 \%$ of the respondents agreed that the strategic plans had never been shared with the students, faculty or made available for public consumption. Finally, the respondents were asked to list the reasons why their institutions contemplated and finally decided to implement SM. The top 3 reasons provided by the leaders were:
a. Increasing Competition
b. Enhanced Threat/Risk Perception due to lower enrollments

\section{c. Enhancing institutional ranking}

\section{- SM Formulation:}

The 53 respondents were further asked to indicate the strategic tools and techniques being employed in their institutions. The list of possible strategic management tools was based on the previous empirical studies. All 53 institutions claimed to have implemented SM tools. However, these institutions conceded to only using SWOT analysis, Customer Satisfaction Analysis and Customer Complaints analysis as tools for SM. The utilization of tools like Scenario Planning, Boston Consulting Matrix (BCG), GE Mckinsey Matrix, Porter's Generic Strategies and Balanced Score Card (BSC) etc. was minimal during formulation of strategy as shown in Fig 3. 29/53 of the respondents conceded hiring an external consultant to help formulate strategic plans for the institution. However, the consultant interactions were limited to the leadership team only. These findings corroborate

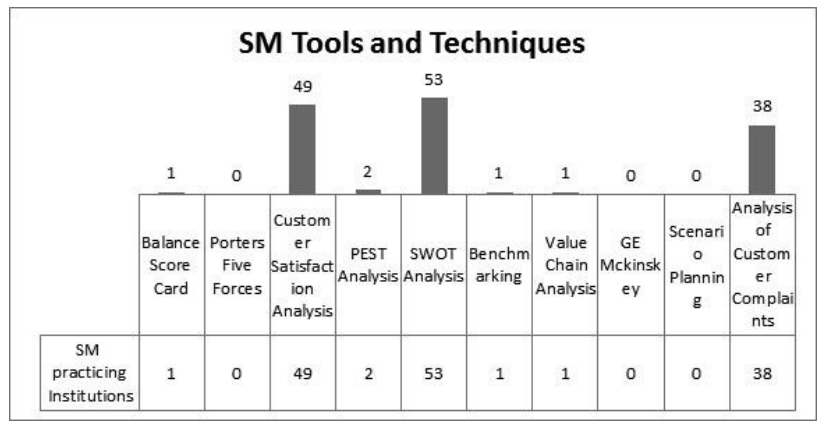

Fig 3. Use of Strategic Management Tools and Techniques 
the low awareness levels pertaining to formal SM by leaders in IHE institutions.

These leaders were also asked to spell out the key elements of their strategic plan. The top responses included:

\section{a. Student Mobilization and Admissions \\ b. Student Placements \\ c. High quality Faculty recruitment}

It was interesting to note that the strategic focus of these institutions was more on input/output related processes and none of the institutions were focused on building organizational excellence, research \& development, innovation, student experience, societal outreach, IT-adoption and branding and reputation which routinely figure in the strategic plans of top international universities.

- Strategy Implementation, Monitoring and Tracking: 33/53 institutions responded that there was no clear allocation of responsibility for implementing strategic plans and delivering on strategic goals. None of the institutions had created a special office or position to drive institution-wide strategic implementation and execution. Only 10 out of the 53 SM practicing institutions conducted periodic meetings to review strategic plans and attainment of strategic objectives. Further, there was no adoption of formal mechanisms or IT tools for the measurement and tracking of strategic objectives. Respondents on being asked felt that measuring, monitoring and tracking progress on strategic objectives is quite difficult, consuming a lot of institutional bandwidth as participation of the entire leadership team is required. Further, the leaders expressed that aligning the second line of leadership to the institutions strategic plan is a major challenge which makes it difficult to build a common view of strategic objectives among all stakeholders.

\section{B. Strategic Management Maturity}

The SM practicing institutions (53) were further tested on a set of questions based on eight dimensions of the standard Strategic Management Maturity Model (SMMMTM) devised by the Balance Score Card Institution (The Strategic Management Maturity Model, BSCI) to gauge the maturity level of SM in their respective institutions. These questions were
Table 6 : Maturity level of SM in practicing institutions

\begin{tabular}{|l|l|l|}
\hline Level & $\begin{array}{l}\text { Number of } \\
\text { Institutions }\end{array}$ & \multicolumn{1}{|c}{ Description } \\
\hline $\begin{array}{l}\text { 1-Ad-hoc and } \\
\text { Static Mechanism }\end{array}$ & 31 & $\begin{array}{l}\text { Institutions do not undertake any formal strategic planning or } \\
\text { management, tend to plan only on tactical or operation level } \\
\text { in an ad hoc and uncontrolled manner, normally by senior } \\
\text { management behind closed doors }\end{array}$ \\
\hline 2-Reactive & $\begin{array}{l}\text { These institutions utilize some elements of effective strategic } \\
\text { planning and strategic performance in an inconsistent } \\
\text { fashion which yields below par results }\end{array}$ \\
\hline $\begin{array}{l}\text { 3-Structure and } \\
\text { Proactive }\end{array}$ & 6 & $\begin{array}{l}\text { These institutions have formal structures and processes in } \\
\text { place to comprehensively and proactively engage in strategic } \\
\text { planning and management }\end{array}$ \\
\hline $\begin{array}{l}\text { 4-Managed and } \\
\text { Focused }\end{array}$ & 2 & $\begin{array}{l}\text { It is characteristic of organizations at this level that strategy } \\
\text { drives fo cus and decision making for the organization. } \\
\text { Organization-wide standards and methods are broadly } \\
\text { implemented for strategy management. }\end{array}$ \\
\hline $\begin{array}{l}\text { 5-Continuous } \\
\text { Improvement }\end{array}$ & 0 & $\begin{array}{l}\text { It is a characteristic of organizations at this level that the } \\
\text { strategic planning and management excellence are embedded } \\
\text { within the culture of the organization and are continuously } \\
\text { improved in a formal sense. }\end{array}$ \\
\hline
\end{tabular}

embedded within our questionnaire. Based on the responses, these 53 institutions were categorized into different SM maturity levels as given below in the Table 6

These leaders were asked to select the positive outcomes resulting from the adoption of SM in their respective institutions. Their top responses were:

a) Increased institutional clarity and focus

b) Enhanced quality of planning

c) More efficient and timely execution of plans

Seven institutions attributed higher student enrollments and increased revenue to the adoption of SM. The mean of the number of years since implementation of SM in these institutions came to be 4 years with the longest practicing institution claiming to have adopted SM 8 years ago. Thus, formal SM adoption is still in a nascent stage in India reflected in the low levels of SM maturity as determined by the SMMMTM.

Finally, these institutions were also asked to select the top challenges during the implementation of SM. Their top responses are listed below:

a) Time consuming and complex to plan and implement

b) Difficult to track effectiveness of SM

c) Difficult to train/orient faculty members

d) Difficult to sustain quality of strategic planning and implementation across different schools/departments 
e) Not sure on how to involve students in SM

\subsubsection{Attitude of Institutional Leaders in IHE towards SM}

The 315 leaders who were practicing informal $\mathrm{SM}$ in their institutions were further questioned to understand their attitude and preferences towards the adoption of formal SM in their institutions. 276/315 leaders said that their institutions are ready to adopt and implement formal SM provided some external help and organizational hand-holding during the process is available. 296respondents rated SM as a complex process which is difficult to comprehend, assimilate and implement at all levels in the institution. Moreover 237/315 leaders also felt the strong need of formal training and workshops on SM for the leadership team. These leaders cited the following challenges which restrict the effective implementation of SM:

1. Driving cultural change in the institution

2. Lack of management buy-in and support

3. Lack of skilled resources and exposure within the institution

4. Lack of accountability

5. Lack of incentives as well as disincentives

4. Conclusion and Future Work

The present work consolidates results from a survey of 368 leaders in the Indian Higher Education sector to gauge the extent and maturity of adoption of Strategic Management at their respective institutions. From the survey, we conclude that:

a. The penetration level of SM is very low and is restricted only to few institutions. Only $26 \%$ of the respondents reported using some form of SM at their institutions.

b. There is significant awareness about the role of SM as a leadership tool among the leaders in IHE but still there exists a large vacuum in the implementation of this modern management practice across institutions in India.

c. SM practices are not broad-based through the institution and tend to be restricted to key people in these institutions, typically from non-academic backgrounds.

d. SM adoption at institutions located in tier-3 and tier-4 cities is abysmally low, the reasons mostly being lack of awareness, skills, resources, leadership and management support.

e. The analysis of maturity levels of SM practicing institution depicts that around 60 percent of the institutions had an adhoc approach towards the Strategic Management whereas 15 percent institutions were reactive institutions. Only 7 percent institutions had formal structures and processes in place, 2 percent of the institutions had well defined strategic plans where as none of the institution had Strategic Management embedded within their culture.

f. The leaders surveyed while expressing the urgent need of SM adoption had cited the inherent complexity of SM as a deterrent which hinders its effective comprehension, assimilation and implementation. The leaders also stressed the need for institution-wide training and handholding by experts in helping institutions devise strategic plans and practice formal SM.

These findings are significant as the IHE is currently at an inflection point and needs to rapidly effect transformation to ensure its relevance going forward. There is also a clear need to develop customized SM models suited for IHE, which are simplified and implementation oriented in nature. Our future work will focus on devising a simplified strategic management framework after analyzing and evaluating the applicability of existing SM frameworks in the higher education institutions. A simplified SM framework with standardized checklists, templates and IT-tools to measure and track strategic objectives will aid the institutions in successfully adopting SM and become competitive. This will help enhance the quality and performance across individual institutions and ultimately IHE in times to come.

\section{References}

[1] (2016) . Retrieve d fr om https://w ww. timeshighereducation.com/world-universityrankingsArmacost, R., Pet-Armacost, J., \& Wilson, A. (2004)s. Innovative integration of strategic planning, benchmarking and 
assessment. 39th International Conference of the Society for College and University Planning (pp.22-34), Toronto, Canada

[2] Bryson, J. M. (1988). Strategic Planning for profit and non-profit organisations. Long Range Planning, 21(1), 73-81

[3] Bryson, J. M., \& Alston, F. K. (1996). Creating and implementing your strategic plan: A workbook for public a nd non- profit organizations. San Francisco: Jossey-Bass.

[4] Chandler, A. D. Jr. (1962). Strategy and Structure: Chapters in the History of the Industrial Enterprise. Cambridge, MA:MIT Press Cambridge

[5] Cope, R. G. (1987. Opportunity from Strength: Strategic Planning Clarified with Case Examples. ASHE-ERIC Higher Education Report No. 8.

[6] Cotter, M., \& Paris, K.A.(2007). Survey of Strategic Planning Practices in Higher Education. Office of Quality Improvement, University of Wisconsin-Madison

[7] Council, B. (2013). A Brief overview of Chinese Higher Education System.India: British Council.

[8] David, F.R. (2009). Strategic Management: Concepts and Cases. 12th ed. FT Prentice Hall, p. $36-37,45-47,93$

[9] Gupta, A. (2005). Securing the future of the indian it industry: a case for educational innovation; challenges and the road ahead. International Journal of Industry and Higher Education.19(6), 423-431

[10] Hinton, K. E. (2012). A practical guide to strategic planning in higher education. Society for College and University Planning.

[11] Hunt, C. M., Oostiing, K. W., Stevens, R., \& Loudon, D. (n.d.). Strategic Planning for private higher education. New York: Haworth Press.

[12] Jauch, L. R., \& Glueck, W. F. (1988). Business policy and strategic management. McGraw-Hill.
[13] Kaplan, R. S., \& Norton, D. P. (2001). The strategy-focused organization: How balanced scorecard companies thrive in the new business environment. Harvard Business Press.

[14] Keller, G. (1983). Academic Strategy: The Management revolution in American Higher Education. Baltimore: Hopkins University Press.

[15] Kozami, A. (2002). Business Policy and Strategic Management, 2e.Tata McGraw-Hill Education.

[16] Mintzberg, H. (1994a). The rise and fall of strategic planning. Englewood Cliffs, NJ: Prentice Hall.

[17] Mintzberg, H. (1994). The rise and all of Strategic Planning: Reconceiving Roles for Planning, Plans, and Planners. New York, NY: The Free Press

[18] Morden, T. (2007). Principles of Strategic Management (3rd ed). UK: MPG Books Ltd.

[19] Nag, R., Hambrick, D. C., \& Chen, M. J. (2007). What is strategic management, really? Inductive derivation of a consensus definition of the field. Strategic management journal, 28(9), 935-955.

[20] Nickols, F. (2011). Strategy, strategic management, strategic planning and strategic thinking. Distance Consulting LLC, 1-8.

[21] Pingle, S., \& Kaul, N. (2011). Performance Management in Insititutes of Higher Education Through Balance Scorecard: A Conceptual Study. GFJMR, 2(2), 34-49

[22] Porter, M. E. (1980). Competitive strategy: Techniques for analyzing industries and competition. New York, 300.

[23] Raghunandhan, T. (2009). Strategy: A Pedagogy for Efficient, Accountable and Socially Responsive Higher Education. Golbal Business and Management Research., 1 (1)

[24] Raghunandhan, T., \& Sequeria, A. H. (2013). Strategic Management in Centrally Funded Technical Institutions In India. International 
Journal of Management Research and Business

Strategy.,2(1), 15-32

[25] The Strategic Management Maturity ModelTM. $(\mathrm{n} . \mathrm{d}$.$) . R e t r i e \mathrm{v}$ e d f r o m http://www.balancescorecard.org

[26] Sawhney S., Gupta A.,\& Kumar, K. (2017). A Case for Strategic Management in Higher Education in India. In: Benlamri R., Sparer M. ( e d s ) Le adership, In novationan $d$ Entrepreneurship as Driving Forces of the
Global Economy. Springer, Cham, pp.403-410

[26] Stoner, J. A. F. (1978). Management. New Jersey: Prentice Hall.

[27] Stukalina, Y. (2014). Strategic management of higher education institutions. Management of Organizations: Systematic Organization

[28] Tabatoni, P., Barblan, A. (2002). Strategic Management, A Tool of Leadership - Concepts and Paradoxes. Thema, 2, European University Association, pp. 5-11. [Online] Available at: 